\title{
THE 1978 BROCKPORT CONFERENCE
}

The comparative history of sport and leisure was the theme of the 10th annual Brockport Conference in Social-Political History, which was held October 6 and 7, 1978. The Department of History, State University of New York at Brockport, and the Social Science History Association co-sponsored the Conference.

British soccer was the topic of the first session. Steven Tischler (Columbia University) argued in his paper, "Class Relationships in British Football, 1880-1914," that with the emergence of commercialization, the class exclusivity of soccer was replaced by new class tensions between wealthy owners aware of their role as businessmen and players equally aware of their role as hired employees. Joseph White (University of Pittsburgh) presented "Football, Class, and Culture," which surveyed some of the structural and regional factors in the rise of professional soccer and presented a case study of teenagers and soccer in the West Midlands in the 1950s.

In the second session, panelists reported on their experience in teaching undergraduate courses in the history of sport. Donald Mrozek (Kansas State University) observed that since no history courses are required at Kansas State, his course might well be undergraduates' only exposure to history. Distinguishing between what is truly unique to sport and what is not thus takes on special importance. Robert Doherty (Pittsburgh) elaborated on the challenge of teaching sports history by relating the discomfort many students show when pushed to question their assumptions that competition and victory count for everything. Richard Smethurst (Pittsburgh) found that students can be startingly ethnocentric. To correct this bias, he includes a cross-cultural analysis of baseball that looks at the United States, Latin America and Japan, as well as an analysis of Japanese Sumo wrestling. William Sharpless (University of Wisconsin, Madison) was concerned with the methodology and conceptual framework most appropriate for teaching sports history to undergraduates. He warned against "nostalgia effect," which he attributed (a bit provocatively?) to the influence of Frederick Engels and suggested that the sociology of religion might provide a viable model for the study and teaching of sports history.

In the final session, Peter Levine (Michigan State University) presented "The Promise of Sport in AnteBellum America." Middle class reformers between 1820 and 1860 , he argued, discovered not only that sport made for a sound mind in a sound body but also that widespread participation in sport could help assure the republic's future. The main finding of Roy Rosenzweig's (Worcester Polytechnic Institute) "Reforming Working Class Play: The Development of Parks and Playgrounds in Worcester, Massachusetts, 1870-1920," was that in Worcester working people partially reshaped the reformers' handiwork to their own purposes by their successful 
insistence upon using parks in working class neighborhoods as they themselves desired.

In the course of commentary and discussion a firm consensus emerged that sport is indeed an integral part of social history, but that it is an autonomous development in its own right and not just a "reflection" of some more basic trends. This was not perhaps a surprising conclusion for a gathering of social historians. However, agreement as to what constituted the most important questions in sports history and the most appropriate conceptual framework remained somewhat elusive. And since sport does not for the most part appear in history as a "movement" or a "problem," this would seem to place the task of defining problematics squarely with the historians. To judge from the presentations at Brockport, the results should be quite stimulating.

\section{Joseph White}

University of Pittsburgh

\section{BREMEN CONFERENCE ON AMERICAN LABOR AND IMIMIGRATION HISTORY}

What questions are European scholars asking about American working class history? Judging by the papers presented to a symposium on American Labor and Immigration History, convened and orchestrated by Dirk Hoerder at the University of Bremen, November 13-17, 1978, three issues command current attention: insurgency, immigration, and socialism.

The first is the most provocative. To scholars who experienced the French May or the Italian Autumn of the late 1960s, the proverbial militancy of the American rank and file took on an immediate relevance. It seems only logical that sooner or later someone would turn to the Great Strikes of 1877 , touchstone of mass insurgency, and Marianne Debouzy (Paris) has begun an in-depth investigation of those events. Her paper raised the themes of spontaneous resistance to industrial capitalism and creative organization from below, themes which were also threaded through the work of three Italian delegates to the symposium, who presented papers on the origins of labor historiography as a response to the mass insurgency of the 1880s (Bruno Cartosio), the Industrial Workers of the World in the South (Ferdinando Fasce), and W. E. B. DuBois as the theoretician of worker self-activity among Blacks after the Civil War (F. Gambino). If this kind of inquiry can be conducted across the entire field, American labor history will never be the same.

Immigration is a more familiar topic. A national perspective defined the field of vision for all the papers--why did our countrymen leave and what happened to them when they got there? This proved both a strength (there is 